\title{
Value of Relevance of Other Comprehensive Income in Listing Companies in LQ 45 Index
}

\author{
Linda A. Razak ${ }^{1}$, Haliah$^{2}$, Abd. Hamid Habbe ${ }^{3}$, Asri Usman ${ }^{4}$ \\ \{lindarazak@unismuh.ac.id, haliah@fe.unhas.ac.id, hamidhabbe@gmail.com, asriophu@gmail.com\} \\ Universitas Muhammadiyah Makassar, Indonesia ${ }^{1}$ \\ Faculty of Economics and Business, Hasanuddin University, Makassar, Indonesia. ${ }^{2-4}$
}

\begin{abstract}
This study investigates the relevance of other comprehensive income to returns, using a sample of LQ 45 companies listing on the Indonesian Stock Exchange (IDX) in 2015-2018, and using simple regression analysis. The results found that other comprehensive income is relevant to stock returns; this indicates the existence of OCI information is considered important for decision making. Other comprehensive income includes all changes in the company's net assets that are adjusted to market conditions and are transparent and have a predictive value on future profits so that it can affect the value of the company. One measurement of company value can be measured by looking at the rate of return on company stock returns.
\end{abstract}

Keywords:

Other Comprehensive Income, Stock Return

Article Received: 18 October 2020, Revised: 3 November 2020, Accepted: 24 December 2020

\section{Introduction}

Since the implementation of mandatory inclusion of comprehensive income as separate information in the income statement, the researcher investigates the relevance of that information in the Indonesian capital market. PSAK No. 1 (Revised 2013) which is mandatory for implementation by the company since January 1,2015 , requires that items on unrealized gains and losses are treated the same as items on realized gains and losses (that is, recognized in net income), therefore the items that have not been realized are put into a special item called Comprehensive Income.

Previous empirical studies in several countries have tested the relevance of comprehensive income and have produced different research results. For example [1] revealed that operating income (net income) is a measure of performance and has a predictive value that is better than comprehensive income. On the other hand, [2] found some evidence that confirms that comprehensive income explains annual returns better than net income, and has information content in terms of predictions. [3] found no evidence that comprehensive income items provided relevant relevance information compared to net income. Using experimental research, [4] conducted an experimental study on MBA students, to assess whether there were differences in professional and nonprofessional investor decision making regarding comprehensive income reporting formats, and the results of the study nonprofessional investors relied more on information provided in the performance statement (Comprehensive Income Statement than other presentation formats. Based on various diverse studies, it is difficult to conclude whether comprehensive income reports produce more informative reporting.

Since the entry into force of PSAK 1 (Revised 2013), it has been required to be implemented on January 1, 2015, requiring to include other comprehensive income in the income statement, consisting of five OCI components that must be reported including; (1) 
revaluation of fixed assets, (2) actuarial for defined benefit programs (3) profit and loss on the translation of financial statements and investment assets from business activities abroad, (4) changes in financial assets available for sale and (5) gains and losses cash flow hedges.

This study examines the relevance of Comprehensive Income to stock returns on LQ 45 companies in Indonesia Stock Exchange. This is something quite important to study because the decline or increasing relevance of the value of financial statements in the capital market indicates low or high quality and usefulness of GAAP and regulations issued by standard setters [5]; [6]. Previous empirical research measures the study of the value of comprehensive income relevance using the model [7] which analyzes the relationship between accounting information on stock prices and returns. This relevancy model is used by several researchers namely; [8];[9];[10];[11];[3].

One of the earnings information included does not only come from the results of the company's main activities but also includes account elements that can increase the value of the company's equity, which in this case is reported in the statement of comprehensive income, so that financial information for one period, not only includes profit / loss at the time of the period but also includes an increase or decrease in value of the company's assets, even if the assets have not been sold.

From this, the researcher investigates that whether one of the elements of earnings information, comprehensive income, has relevant value on investment decisions for investors in companies listing in LQ 45.

\section{Theoretical Framework and Hypotheses Development}

Signaling Theory is a signal of information given by management about the condition of the company (Brigham and Houston, 2011). This information is a signal to the company's condition and its impact on future cash flows.
Other comprehensive income information can be a signal for investors in making investment decisions. Since the adoption of PSAK 1 (Revised 2013), which must be implemented by every company since January 1, 2015, requires that every company must include comprehensive income in the income statement. With comprehensive income, it can improve the comparability, consistency and accuracy of financial statements. OCI information contains information measured at fair value so that the information is more relevant to market conditions.

\section{Hypotheses Development}

The decision to include OCI as part of the income statement is considered to be able to present more complete financial statement position information for the decision making process in increasing the relevance of the financial statements as a whole. OCI is considered to be able to increase transparency of important information regarding unrealized fair value gains and losses in the future. OCI contains information on the fair value of assets and debt so that OCI provides more transparent information about the company's current condition. OCI can give a signal to investors, if the signal is considered valuable then the market will respond to that signal.

Research [2]tests three benefits of OCI; information content, OCI predictability and executive compensation contracting. And the results of the study. Comprehensive income explains better annual returns than net income, and has information content, in terms of predictions, OCI has better predictive ability than NI, and in terms of executive compensation contraction, NI is able to explain compared to CIs. Empirical studies in research [8] show that other comprehensive income has a stronger relevance relationship to stock returns than net income. The results of the study found evidence that current year earnings were predicted by comprehensive income last year, so comprehensive income was considered relevant to be used as the presence of new information for investors. 
H1: Comprehensive Income has a relevant effect on stock returns

\section{Research Methods}

This study is a hypothesis test, researchers investigated the correlation between the relevance of comprehensive income relevance to stock returns. Time dimension This research involves many specific time (time series) with many companies (cross section). Data collection methods used are archival data collection. The type of company studied is the LQ 45 listed company on the Indonesian Stock Exchange for 2015-2018.

\section{Stock returns}

Stock return is income (gain) or loss (loss) due to a decrease in the value of an investment in a certain period. Measurement of returns using model [7] is by looking at the level of stock returns.

$$
R_{i t}=\frac{\left(P_{t}-P_{t-1}\right)}{P_{t-1}}
$$

$\mathrm{R}_{\mathrm{it}} \quad=$ Return of company $\mathrm{i}$ stock in period $\mathrm{t}$

$\mathrm{Pt}=$ closing price of company shares in period $\mathrm{t}$

$\mathrm{P}_{\mathrm{t}-1} \quad=$ The closing price of the company's shares in the $t-1$ period or period previous.

\section{Other Comprehensive Income Components (X1)}

OCI is an unrealized gain or loss from changes in the equity of a company whose source is not from owner's capital. According to PSAK I (revised 2013) included in the OCI component are revaluation of fixed assets, actuarial for defined benefit programs, foreign exchange differences on financial statements of foreign entities, asset instruments available for sale and cash flow hedging instruments.

$$
\mathrm{OCI}=\frac{O C I}{\text { Total Comprehensive Income }}
$$

OCI $=$ Other comprehensive income report (income comprehensive)

Total OCI = Total overall components of comprehensive income

\section{Data Analysis Method}

Data analysis using regression test with SPSS 24 analysis tool with the following research model;

$$
R_{i t}=\beta_{0}+\beta_{1} \text { OCI }+\varepsilon
$$

\section{$4 \quad$ Result}

\section{Descriptive Statistical Analysis}

Based on the results of the analysis of Table 1 , the number of samples (n) of the research is 45 LQ 45 companies with four (4) years of research time from 2015 to 2018. From the number of samples (n), the OCI variable has minimum and maximum values - 252,13 and 234.18. With a standard deviation of 38.803809 and. And the number of observations is 180 . This shows that the sample quality of company data tends to show that the OCI data of the company is quite high. The result of the minimum return value of -1.06 and the maximum return of the return is 3.32 , this shows that the sample of the company's data return is quite high.

Table 1. Descriptive Statistics

\begin{tabular}{lccccc}
\hline & $\mathrm{N}$ & Minimum & Maximum & Mean & Std. Deviation \\
\hline OCI & 180 & $-252,13$ & 234,18 & 6,8429 & 38,80389 \\
Return & 180 & $-1,06$ & 3,32 &, 0206 &, 45172 \\
Valid N (listwise) & 180 & & & & \\
\hline
\end{tabular}


Table 2. ANOVA ${ }^{\mathrm{a}}$

\begin{tabular}{rlrrrrr} 
Model & & Sum of Squares & Df & Mean Square & F & Sig. \\
\hline 1 & Regression & 1,171 & 1 & 1,171 & 5,894 &, $016^{\mathrm{b}}$ \\
& Residual & 35,354 & 178 &, 199 & & \\
& Total & 36,525 & 179 & & & \\
\hline
\end{tabular}

a. Dependent Variable: Return

b. Predictors: (Constant), OCI

Table 3. Coefficients ${ }^{\mathrm{a}}$

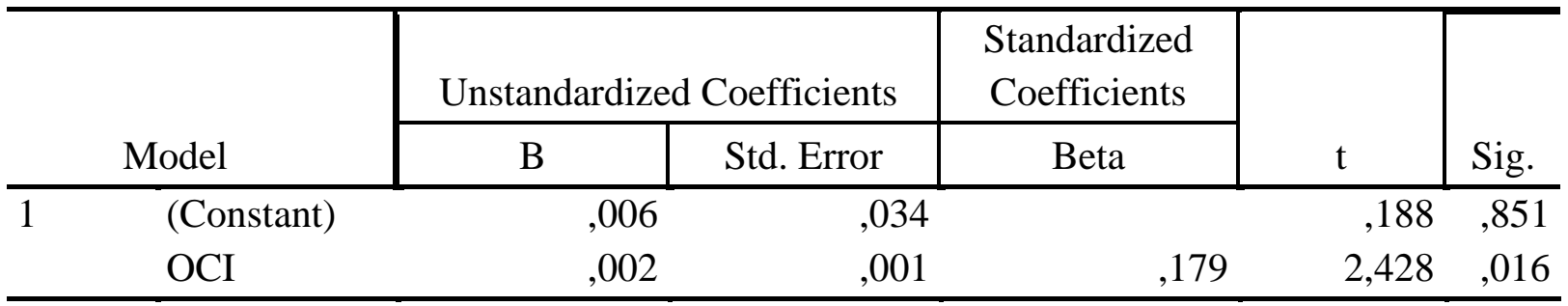

a. Dependent Variable: Return

Table 4. Model Summary ${ }^{\mathrm{b}}$

\begin{tabular}{l|l|r|c|r}
\hline Model & $\mathrm{R}$ & R Square & $\begin{array}{c}\text { Adjusted R } \\
\text { Square }\end{array}$ & \multicolumn{1}{c}{ Std. Error of the Estimate } \\
\hline 1 &, $179^{\mathrm{a}}$ &, 032 &, 027 &, 44566 \\
\hline
\end{tabular}

a. Predictors: (Constant), OCI

b. Dependent Variable: Return

$\mathrm{T}$ test results (hypothesis testing) other comprehensive income for the study sample has a beta coefficient of 0.002 to the Stock Return and a value of $\rho$-value (sig.) Of $0.016<0.05$. OCI variable coefficients that produce positive values are in line with research hypotheses that have a positive influence then $\mathrm{H} 1$ is accepted so that the hypothesis 1 test can be accepted, then OCI has a relevant.

\section{Discussion}

The results of tests conducted show that OCI has a relevant value relationship to stock returns, implying OCI information is considered important. This is caused by the accumulation of profits generated by the company at LQ 45 at IDX is the result of accumulation of total operating profit and other comprehensive income, so an increase in the number of OCI will increase the amount of profits obtained by the company, and this is a role model by investors in making an investment that is by looking at the total amount of profits generated by the company.

The decision to include OCI in the income statement is considered to be a transparent and more complete information in the presentation of decision making information by increasing the relevance of the financial statements as a whole, [12].

Research [13]in Japan related to the relevance of OCI values using a sample of non-financial sector Japanese companies in the 1998-2010 period. The results of his research found evidence that earnings in the current year were predicted by the existence of comprehensive income information from the previous period. so that other comprehensive income is considered relevant to be used as information to predict future net income. [14] stated that the disclosure of OCI's other comprehensive income component becomes important as there is an increase in the complexity of business transactions, such as 
foreign operating activities, corporate pensions, and buying and selling of securities. The five other comprehensive income components according to PSAK I 2009 revision include changes in the revaluation surplus, remeasurement of the defined benefit program, gains and losses arising from the translation of financial statements from foreign business activities, gains and losses from re-measuring financial assets as "available for sale ", and the effective portion of the profits and losses of cash flow hedging instruments.

An obligation for companies to disclose other comprehensive income components should be able to improve the quality of financial reporting and can make the information presented useful by categorizing earnings components in ways that are considered useful to investors. This is because other comprehensive income covers all changes in the company's net assets and becomes a new information presence for investors and can predict future income so as to increase the value of the company. One measurement of company value can be measured by looking at the level of stock returns (return) of the company.

\section{Conclusions And Recommendations}

This research investigates the relevance of other comprehensive income to stock returns. The results of analysis and hypothesis testing concluded that other comprehensive income had a significant effect or had a relevant relationship on stock returns. This is because other comprehensive income covers all changes in the company's net assets and makes managers not only consider internal factors but also external factors that affect the value of the company. One measurement of company value can be measured by looking at the level of stock returns (return) of the company.

For management, the disclosure of comprehensive income must be in accordance with the actual situation. This is because, evaluations of the company's financial performance are carried out comprehensively both realized and unrealized financial data. Management must disclose relevant and fair disclosure of information.

For investors, before investing, it is better to conduct a comprehensive financial performance assessment. The financial data contained in the company's financial statements does not fully reflect the financial condition of the company in real terms. Financial analysis must be performed on all financial data both realized and unrealized. This is to prevent investment losses.

Future studies can expand research samples in all company industries listed on the Indonesia Stock Exchange and add research periods. And also researchers can analyze how the influence of other comprehensive income components in relation to earnings management and market reaction.

For management, the disclosure of comprehensive income must be in accordance with the actual situation. This is because, evaluations of the company's financial performance are carried out comprehensively, both realized and unrealized financial data. Management must disclose relevant and reasonable information.

For investors, before investing, it is better to conduct a comprehensive financial performance assessment. Financial data contained in a company's financial statements do not fully reflect the company's financial condition in real terms, and financial analysis must be carried out on all financial data both realized and unrealized. This is to prevent investment losses.

\section{Reference}

[1] D. Dhaliwal, K. R. Subramanyam, and R. Trezevant, "Is comprehensive income superior to net income as a measure of firm performance?," J. Account. Econ., vol. 26, no. 1-3, pp. 43-67, 1999.

[2] G. C. Biddle and J.-H. Choi, "Is Comprehensive Income Useful?," J. Contemp. Account. Econ., vol. 2, no. 1, pp. 1-32, 2006. 
[3] Cahan et al., "Discussion of value relevance of mandated comprehensive income disclosures," J. Bus. Financ. Account., vol. 27, no. 9-10, pp. 13031309, 2000.

[4] L. S. M. Laureen A.Maines, "Characteristics on Nonprofesional Investors' judgments: The Role of Financial-Statement Presentation Format," Account. Rev., vol. 75, no. 2, pp. 179-207, 2000.

[5] E. Kirsten and W. Gregory, "Special Section on the Relevance of Financial Statements Accounting Standard-Setting Organizations and Earnings Relevance: Longitudinal Evidence Erom NYSE Common Stocks , 1927-93," J. Account. Res., vol. 37, no. 2, pp. 293-318, 1999.

[6] R. W. Holthausen and R. L. Watts, "The relevance of the value-relevance literature for financial accounting standard setting," J. Account. Econ., vol. 31, no. 1-3, pp. 375, 2001.

[7] J. A. Ohlson, "On transitory earnings," Rev. Account. Stud., vol. 4, no. 3-4, pp. 145-162, 1999.

[8] K. Kanagaretnam, R. Mathieu, and M. Shehata, "Usefulness of comprehensive income reporting in Canada," J. Account. Public Policy, vol. 28, no. 4, pp. 349-365, 2009.

[9] Barth., "The relevance of the valuerelevance literature for financial accounting standard setting," J. Account. Econ., vol. 31, no. 1-3, pp. 3-75, 2001.

[10] M. Dastgir and A. S. Velashani, "Comprehensive income and net income as measures of firm performance: Some evidence for scale effect," Eur. J. Econ. Financ. Adm. Sci., vol. 12, no. 12, pp. 123-133, 2008.

[11] J. A. Pinto, "How comprehensive is comprehensive income? The value relevance of foreign currency translation adjustments," J. Int. Financ. Manag. Account., vol. 16, no. 2, pp. 97-122, 2005.
[12] P. M. Dechow and R. G. Sloan, "Executive incentives and the horizon problem. An empirical investigation," J. Account. Econ., vol. 14, no. 1, pp. 51-89, 1991.

[13] Takahashi, "Discussion Paper Series The Usefulness of Other Comprehensive Income Items in Japan," Discuss. Pap. Ser., no. 6059, 2012.

[14] D. A. Jones and K. J. Smith, "Comparing the value relevance, predictive value, and persistence of other comprehensive income and special items," Account. Rev., vol. 86, no. 6, pp. 2047-2073, 2011. 